\title{
The Effects of Capital Adequacy, Credit Risk, and Liquidity Risk on Banks' Financial Distress in Indonesia
}

\author{
Margarita Ekadjaja ${ }^{1}$, Halim Putera Siswanto ${ }^{1 *}$, Agustin Ekadjaja ${ }^{1}$, Rorlen Rorlen $^{1}$

\begin{abstract}
${ }^{1}$ Management Department, Faculty of Economics and Business, Universitas Tarumanagara, Jakarta, Indonesia *Corresponding author. Email: halims@fe.untar.ac.id
\end{abstract}

\begin{abstract}
The ongoing Covid-19 pandemic has caused many companies that cannot adapt to have difficulty in running their business. Banking as a financial intermediary institution has no exception to be affected by this pandemic. When the number of non-performing loan increases and credit distribution decreases, the banks' profits are reduced, which then will cause financial distress. This study aimed to determine the effects of capital adequacy, credit risk, and liquidity risk on banks' financial distress. Using the logit regression equation, the results show that the variables of credit risk and liquidity risk have positive and significant effects on banks' financial distress, while the capital adequacy has a negative and not significant effect on banks' financial distress.
\end{abstract}

\section{Keywords: capital adequacy, credit risk, liquidity risk, banks' financial distress}

\section{INTRODUCTION}

The fluctuating social and economic conditions in a country tend to create instability in the monetary and banking sectors. The ongoing Covid-19 pandemic outbreak causing the companies that cannot adapt will have difficulty to operate. Likewise, industrial sectors that cannot apply social distancing are such as fitness centres, cinemas, beauty cares, and so on. This phenomenon causes great disruption of the economic cycle.

The slowing of the economic cycle accompanied by a decrease in the amount of money circulating in society indirectly causes the profit from the bank to decrease. [11] stated that bank activities are collecting funds in form of saving deposits, demand deposits, and time deposits (thirdparty funds), as well as channelling these funds in form of credits.

The continuity of banking business is not only determined by the amount of demand deposits, savings, and time deposits that can be collected from public, but also by the amount of credit that can be extended to the public. However, lending to public carries a potential risk of credit problems. Along with this crisis, the risk of credit also increases.

Table 1 Loan-to-Deposit Ratio of Commercial Banks

\begin{tabular}{|c|c|}
\hline Year & LDR \\
\hline 2016 & $94.23 \%$ \\
\hline 2017 & $89.09 \%$ \\
\hline 2018 & $92.27 \%$ \\
\hline 2019 & $89.06 \%$ \\
\hline Jun 2020 & $85.08 \%$ \\
\hline
\end{tabular}

Source: Statistik Perbankan Indonesia, 2020
Table 1 describes that banks are currently not providing much credit. This can be seen from the amount of the Loanto-Deposit Ratio (LDR) figure in general, whereas the ratio was $90-95 \%$, but from 2019 to June 2020 the LDR figure was below $90 \%$. The decreasing LDR indicates that credit growth is slower than that of third-party funds growth. If the LDR gets closer to $100 \%$, the bank lacks liquidity, and will usually offer high-interest deposits. Conversely, if the LDR is less than $100 \%$, then the bank has sufficient liquidity so that the deposit interest-rate is relatively low.

According to [8], credit risk arises because of the poor performance of one or more debtors in form of the debtor's inability to fulfil part or all of the contents of the credit agreement that was mutually agreed upon previously.

[3] showed that liquidity risk is an important risk factor that can trigger a potential bank failure and specifically affects bank risk. Liquidity risk occurs in line with bank activities that liquidate their asset below the intrinsic value. This results in a significant loss and reduction in revenue.

According to [17], the bank's credibility in managing the liquidity ratio shows the way the bank overcomes this risk so that it can create value. Banking business processes are strongly influenced by various risks, such as business risk, credit risk, liquidity risk, operational risk, legal risk, and even brand and marketing risk.

The factor that causes a bank to experience liquidity risk is that it is unable to maximize revenue due to the pressure of liquidity needs. Liquidity risk comes from third-party funds, assets, and liabilities on counter parties. One of the liquidity ratios is the Loan-to-Deposit Ratio (LDR). According to [6], LDR is used to determine a bank's ability to meet short term liabilities through the ratio between loan and deposits. Research conducted by [2] proved the relevance of the liquidity ratio and the Capital Adequacy Ratio (CAR) to banks' financial distress. Meanwhile [1] proved that credit 
risk and CAR have a significant influence on banks' financial distress.

This study complements previous research, using asset liability management as a bank's internal factor and the market as an external factor which is under category of a commercial bank with business activities level 1. The reason for using a commercial bank for business activity level 1 is because the bank in this category has more limited funds and is therefore more vulnerable to risks due to the pandemic. The orientation of this research is to measure the banks' financial distress, with the following limitations:

1. How is the effect of capital adequacy on banks' financial distress?

2. How is the effect of credit risk on banks' financial distress?

3. How is the effect of liquidity risk on banks' financial distress?

\subsection{Related Work}

This research is included in the applied research category with the aim of applying the research that has been conducted by previous researchers. [2] conducted a study among banks in Europe that experienced financial distress with reference to Basel III. The variables used in the study are structural liquidity and capital ratio. The results of the study prove that there is a significant effect of structural liquidity and capital ratio on banks' financial distress. [4] conducted a study on bank bailouts and moral hazard among banks in Germany. This research also provides the evidence that banks in Germany experience financial difficulties due to their credit failures.

[18] conducted a study measuring the financial difficulties among Malaysian banks through the banks' healthiness ratio analysis (CAMEL $=$ Capital Asset Management Earning and Liquidity). The variable testing method used was two stage to prove the relationship between the dependent variable, in this case financial distress, to the independent variable, namely the banks' management ratio and the banks' financial ratio including capital, assets, earnings, and liquidity ratios.

[13] proved that there is a negative relationship between banks' distress in the US and credit collectability in capitalintensive R\&D companies during the global crisis.

[1] conducted a research on banks' distress using credit risk and capital adequacy variables. The measurement of banks' distress is through the credit risk indicator, namely dividing Earnings Before Interest \& Tax with Interest Expenses. If the credit risk indicator is less than 1 , the bank is in a state of distress. Conversely, if the credit risk indicator is greater than or equal to 1 , the bank is in not distress. The results prove that there is a positive and significant relationship between credit risks and banks' distress in Indonesia. On the other hand, the relationship between CAR and banks' distress in Indonesia is negative and significant.

According to [9], collectability is a description of the conditions for repayment of loan principal and interest as well as the likelihood that the invested funds will be returned. The ratio to measure a bank's ability to protect the risk of credit default by debtors is called Non-Performing Loan (NPL).

\subsection{Our Contribution}

This paper presents some improvements based on [7], whereas regardless of maturity mismatch, liquidity risk arises due to the economic recession conditions and the lack of resources. This increases the demand for depositors to create liquidity risk and lead to failure of certain banks or the entire banking system due to the effects.

In this research, we conducted the steps as follows:

1. Examining the literature in form of the theories regarding banks' financial distress, capital adequacy, credit risk, and liquidity risk.

2. Identifying the independent variables such as Capital Adequacy Ratio (CAR), Non-Performing Loan (NPL), and Loan-to-Deposit Ratio (LDR). Dependent variable is the banks' financial distress.

3. Collecting secondary data in form of financial reports of banking companies registered in the Financial Services Authority (OJK)

4. Performing tabulation, data processing, and hypothesis testing. Data processing used the Eviews 9.0 application program.

5. Interpreting the regression model, in which this study used a logit regression model.

\section{LITERATURE AND HYPOTHESIS}

\subsection{Grand Theory}

The banking industry is a business full of risks, even though the business prospects are good and managed prudently. This is due to the fact that most banks' activities rely on third-party funds such as demand deposits, savings, and time deposits. Those three banking instruments have high amount-fluctuations, which do not always match the moments of credit placements.

Banks provide credit, because they believe that credit customers are able to fulfil everything that has been promised. However, the provision of bank credit sometimes deviates from the expectation, whereas the debtor and / or other parties fail to fulfil their obligations to the bank.

According to [7], the greater the distribution of funds in form of credit relative to deposits or public deposits in a bank may bring consequences, which is the greater the risk borne by the bank's concern. If credit disbursement experiences failures or problems, the bank will experience difficulties in returning the funds deposited by the public. Thus, to avoid this from happening, banks must determine the optimal liquidity risk management policies.

\subsection{Hypothesis}

Based on the results of the research conducted by [12], CAR, which is part of CAMEL, contributes the most to the 
measurement of banks' financial distress. The data used ranges from the year 1992 to 2012 among US banks which refer to Basel III.

[14] proved that CAR has a positive and significant effect on banks' distress. Meanwhile, [5] found that CAR has a negative and significant effect on banks' distress. Based on this statement, the first hypothesis in this research is: $\mathrm{H}_{1}=$ Capital Adequacy Ratio has a negative and significant effect on the measurement of banks' financial distress.

[1] found that credit risk has a positive and significant effect on banks' financial distress. This is in contrast to the results of the research by [14] which proved that the NonPerforming Loan ratio has a negative and insignificant effect on banks' financial distress. Based on this statement, the second hypothesis in this research is: $\mathrm{H}_{2}=$ Credit risk has a positive and significant effect on the measurement of banks' financial distress.

[19] conducted research among Conventional Banks in Indonesia and argued that the liquidity ratio (loan-to-deposit ratio) had no significant effect on the level of banks' financial distress. Meanwhile, [3] argued that the liquidity ratio, which is proxied by the loan-to-deposit ratio, has a positive and significant effect on the level of banks' financial distress. Based on this statement, the third hypothesis in this research is: $\mathrm{H}_{3}=$ Liquidity risk has a positive and significant effect on the measurement of banks' financial distress.

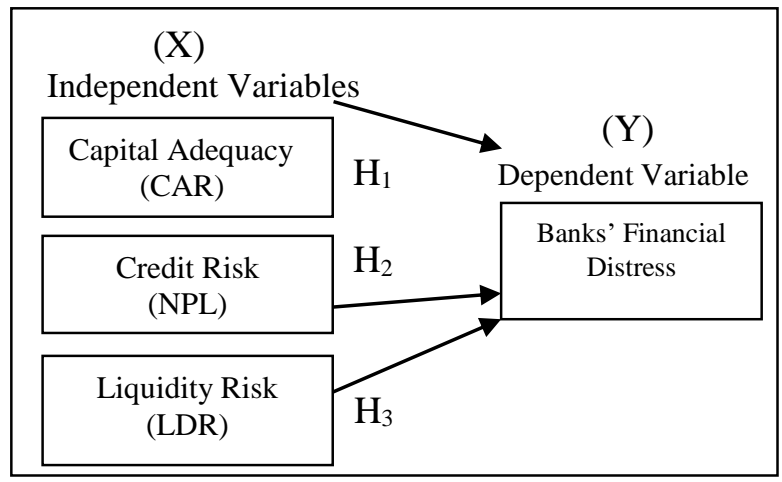

Figure 1 Conceptual Framework

Source: Data Analysis, 2020

Figure 1 shows that the independent variables are capital adequacy as proxied by Capital Adequacy Ratio (CAR), credit risk as proxied by Non-Performing Loan (NPL), and Liquidity risk as proxied by Loan-to-Deposit Ratio (LDR). The dependent variable is the banks' financial distress.

This study used logit regression with the research equation model as follow:

$$
\mathrm{OR}=\beta_{0}-\beta_{1} \mathrm{CAR}+\beta_{2} \mathrm{NPL}+\beta_{3} \mathrm{LDR}
$$

Table 2 The Operationalization of Variables

\begin{tabular}{|l|l|l|}
\hline Variable & \multicolumn{1}{|c|}{ Measurement } & \multicolumn{1}{c|}{ Indicator } \\
\hline $\begin{array}{l}\text { Banks' } \\
\text { financial } \\
\text { distress } \\
\text { (Distress) }\end{array}$ & $\begin{array}{l}\text { Z=1,650 (Working } \\
\text { Capital/Total Asset) }+3,404 \\
\text { (EBIT/Total Asset) }-\end{array}$ & $\begin{array}{l}\mathrm{Z} \leq-0,02 \\
\mathbf{m} \text { distress } \\
\mathrm{Z} \geq 0,01 \\
\rightarrow \text { not distress }\end{array}$ \\
\hline $\begin{array}{l}\text { Capital } \\
\text { Adequacy }\end{array}$ & $\frac{\text { Bank's Capital }}{\text { Risk Weighted Assets }} \times 100 \%$ & $\begin{array}{l}\text { CAR } \geq 8 \% \\
\rightarrow \text { healthy } \\
\text { bank }\end{array}$ \\
\hline $\begin{array}{l}\text { Credit } \\
\text { Risk } \\
\text { (NPL) }\end{array}$ & $\frac{\text { Non Performing Loan }}{\text { Total Loan }} \times 100 \%$ & $\begin{array}{l}\text { NPL }<5 \% \\
\rightarrow \text { healthy } \\
\text { bank }\end{array}$ \\
\hline $\begin{array}{l}\text { Liquidity } \\
\text { Risk } \\
\text { (LDR) }\end{array}$ & total loan \\
\hline
\end{tabular}

Source: [10] and [11]

Table 2 shows the measurement of banks' financial distress using the Grover Model [15]. A bank is considered to experience financial distress, if the $\mathrm{Z}$-value is smaller than or equal to -0.02. A bank's financial condition is considered to be good, if the Z-value is greater than 0.01. Measurement of the variable of capital adequacy is proxied by the Capital Adequacy Ratio (CAR). Credit risk is proxied by the NonPerforming Loan Ratio (NPL) and liquidity ratio is proxied by the Loan-to-Deposit Ratio (LDR).

\section{METHODOLOGY}

This study used secondary data obtained from the financial reports of Commercial Banks', whose business activities are categorized as level 1 . The sampling process was carried out purposively, with the following criteria: The Commercial Bank has complete financial reports from the year 2011 to 2018. Based on data [16] regarding 13 commercial banks whose business activities were categorized as level 1 , there were 10 banks that met the criteria with a total of 80 observation data

The selection of variables used the assistance of NVIVO 12 software with the criteria for selecting variables that have an influence on financial distress, then we tested the variables using the Eviews application. The dependent variable is Banks' Financial Distress, and the independent variables are capital adequacy (proxied by CAR), credit risk (proxied by NPL), and liquidity risk (proxied by LDR). Statistical data based on the Likelihood function, is tested for the hypothesis after the Likelihood (L) is transformed into $-2 \operatorname{LogL}$. After that, a binary logit regression analysis was performed by using the Eviews application.

Description:

$\mathrm{OR}=$ Odds ratio $=\mathrm{Ln}\{\mathrm{P} /(1-\mathrm{P})\}$

$\beta_{0}=$ Constant

$\beta_{1-3}=$ Coefficient 


\section{RESULTS AND DISCUSSIONS}

\subsection{Descriptive Statistics}

Table 3 Descriptive Statistical Test Results

\begin{tabular}{lcccc}
\hline & Distress & CAR & NPL & LDR \\
\hline \hline Mean & 0.500000 & 14.66050 & 0.880125 & 86.71863 \\
Median & 0.500000 & 12.85500 & 0.385000 & 85.56000 \\
Maximum & 1.000000 & 28.50000 & 4.960000 & 111.8400 \\
Minimum & 0.000000 & 11.54000 & 0.021000 & 66.55000 \\
Std. Dev. & 0.503155 & 11.58980 & 1.145077 & 10.26400 \\
Skewness & 0.000000 & 2.515976 & 1.937632 & 0.411154 \\
Kurtosis & 1.000000 & 11.41039 & 6.476342 & 2.814348 \\
JarqueBera & 13.33333 & 320.1841 & 90.34209 & 2.368862 \\
Probability & 0.001273 & 0.000000 & 0.000000 & 0.305920 \\
Observation & 80 & 80 & 80 & 80 \\
\hline Source: Data Analysis, & $\mathbf{2 0 2 0}$ & &
\end{tabular}

Source: Data Analysis, 2020

Table 3 Descriptive Statistical Test Rail, indicates that the average commercial bank experiencing financial distress from 2011-2018 was 0.5 or $50 \%$, which means that from a sample of ten banks, five banks experienced financial difficulties, with indicator number 1 indicating the bank was financial distress, and the indicator number 0 shows the bank is non-financial distress. Based on the bank's soundness level of capital adequacy from 2011-2018, this commercial bank is still in a healthy category due to its Capital Adequacy Ratio (CAR) $>8 \%$, with a maximum CAR value of 28,50000 and a minimum CAR value of $11.54,000$. In terms of credit risk, it appears that banks can still control their credit. This can be seen from the bank's Non-Performing Loan (NPL) ratio $<5 \%$. With a maximum NPL value of 4.960000 and a minimum NPL value of 0.021000 . In terms of liquidity risk, it was identified that the health of a commercial bank from 2011-2018 was still categorized as a healthy bank. This can be seen from the average limit of the Bank's Loan to Deposit Ratio, which is still in the safe category, namely 86.71863. However, LDR data can also indicate that commercial banks whose business activities are categorized as level 1 do not provide much credit, where the average LDR value is below 100.This is likely due to the crisis triggered by the covid-19 pandemic.

\subsection{Model Analysis}

Table 4 Goodness-of Fit Evaluation for Binary Specification

\begin{tabular}{|c|c|c|c|c|c|c|c|c|}
\hline & \multicolumn{3}{|c|}{ Quantile of Risk } & Dep $=0$ & \multicolumn{2}{|c|}{ Dep $=1$} & Total & \multirow{2}{*}{$\begin{array}{c}\text { H-L } \\
\text { Value }\end{array}$} \\
\hline & Low & High & Act & Expect & Act & Expect & Obs & \\
\hline 1 & 0.0008 & 0.0364 & 8 & 7.90005 & 0 & 0.09995 & 8 & \\
\hline 2 & 0.0467 & 0.1950 & 6 & 7.02873 & 2 & 0.97127 & 8 & \\
\hline 3 & 0.2211 & 0.3500 & 6 & 5.74753 & 2 & 2.25247 & 8 & \\
\hline 4 & 0.3593 & 0.4660 & 6 & 4.62414 & 2 & 3.37586 & 8 & \\
\hline 5 & 0.4693 & 0.6208 & 4 & 3.54852 & 4 & 4.45148 & 8 & \\
\hline 6 & 0.6288 & 0.6735 & 2 & 2.72963 & 6 & 5.27037 & 8 & \\
\hline 7 & 0.6915 & 0.7107 & 4 & 2.39361 & 4 & 5.60639 & 8 & \\
\hline 8 & 0.7125 & 0.7358 & 1 & 2.18821 & 7 & 5.81179 & 8 & \\
\hline 9 & 0.7366 & 0.7612 & 0 & 2.02601 & 8 & 5.97399 & 8 & \\
\hline \multirow[t]{2}{*}{10} & 0.7617 & 0.7983 & 3 & 1.81357 & 5 & 6.18643 & 8 & \\
\hline & \multicolumn{2}{|c|}{ Total } & & 40.0000 & 40 & 40.0000 & & \\
\hline \multicolumn{3}{|c|}{ H-L Statistic } & \multicolumn{2}{|c|}{8.8934} & \multicolumn{2}{|c|}{ Prob. Chi-Sq (8) } & \multicolumn{2}{|c|}{0.3514} \\
\hline \multicolumn{2}{|c|}{ Andrews Statistic } & & \multicolumn{2}{|c|}{17.7835} & \multicolumn{2}{|c|}{ Prob.Chi-Sq (10) } & \multicolumn{2}{|c|}{0.0487} \\
\hline
\end{tabular}

Source: Data Analysis, 2020

Table 4 about Goodness-of-Fit shows that the model in this study is appropriate, which can be seen in the Chi-Sq (8)
Prob value of 0.3514 , which is greater than $5 \%$ significance level. 
Table 5 Expectation Prediction Evaluation for Binary

\begin{tabular}{lrrr} 
& \multicolumn{2}{c}{ Estimated Equation } & \\
& Dep $=0$ & Dep $=1$ & Total \\
\hline \hline P(Dep=1)<=C & 27 & 7 & 34 \\
P(Dep=1)>C & 13 & 33 & 46 \\
Total & 40 & 40 & 80 \\
Correct & 27 & 33 & 60 \\
\% Correct & 77.50 & 82.50 & 85.00 \\
\% Incorrect & 17.50 & 12.50 & 15.00 \\
Total Gain* & -32.50 & 82.50 & 25.00 \\
Percent Gain** & $\mathrm{NA}$ & 82.50 & 50.00 \\
& & & \\
& &
\end{tabular}

Source: Data Analysis, 2020

Table 5. Expectation Prediction shows that among 80 observations, it is estimated that there were 40 commercial banks experiencing financial distress and there were 40 commercial banks not experiencing financial distress, with an accuracy rate of $85 \%$.

\subsection{Logistic Regression Analysis}

Table 6 Logistic Regression Results

\begin{tabular}{crrrr}
\hline \hline Variable & Coefficient & Std. Error & z-Statistic & Prob. \\
\hline \hline CAR & -0.022690 & 0.031305 & -0.724823 & 0.4686 \\
NPL & 1.654956 & 0.507914 & 3.258336 & 0.0011 \\
LDR & 1.018740 & 0.261886 & 2.697019 & 0.0458 \\
C & 0.032498 & 2.206649 & 0.014728 & 0.9882 \\
\hline \hline
\end{tabular}

McFadden

R-squared

0.735180 Mean dependent var

0.500000

Obs with

Dep $=0$

Obs with

Dep $=1$

40 Total observation

80

Source: Data Analysis, 2020

The Logistic Regression Results in Table 6 shows that the variables that affect banks' financial distress are credit risk and liquidity risk. This is evidenced by the probability value of credit risk variable as proxied by NPL which is less than the $5 \%$. Likewise, the liquidity risk also has the probability value less than $5 \%$.

Meanwhile, the variable of capital adequacy, which is proxied by CAR, has a probability value greater than $5 \%$, so the capital adequacy is not significant to the measurement of banks' financial distress.

Based on Table 6 about the Logistic Regression Results, the following research equation can be formulated as follow:

\footnotetext{
$\mathrm{OR}=0.032498-0.022690 \mathrm{CAR}+1.654956 \mathrm{NPL}$$$
+1.018740 \mathrm{LDR}
$$

The research equation shows that the CAR variable has an opposite relationship, in which if a bank's capital adequacy increases, then it will experience financial distress. This is in line with research [5] with the increasing CAR value causing the bank to experience financial distress. The large CAR value is due to an increase in the amount of bank capital which is not accompanied by providing credit to customers, so that the bank's income is reduced. At this time, whereas the Covid-19 pandemic has caused many businessmen to go bankrupt due to the slow pace of the economy, many entrepreneurs postpone their business development or start their business to run, which in turn would affect the demand for credit from banks.

Credit risk has a positive and significant effect on banks' financial distress. This is in line with the research results [1], in which the greater the value of NPL, the greater the NPL ratio will be. So, there is a deviation from the income that is expected to be received by the bank. In line with the pandemic that occurred, many debtors were unable to fulfil their obligations, thus affected the banks' profits, which in turn they experienced financial distress.

Likewise, the liquidity risk variable, based on the research results, has a positive and significant effect on the measurement of banks' financial distress. This is in line with the research result from [3], whereas the LDR is an important ratio in predicting a bank's performance. Thirdparty funds that are successfully collected by the bank can incur interest expenses, so the bank must be able to cover these costs.

If the LDR is less than $100 \%$, then the bank has sufficient liquidity so that the deposit rate is relatively low. This is in line with the Bank of Indonesia's actions to continue to lower the interest rates. The decrease in the interest rate has caused the public to divert their funds to investments in other instruments outside banking products.

Likewise, the LDR value has been decreasing since 2019 indicating that the banks are putting the brakes on lending. This is done by the bank to avoid even more losses. In this study, McFadden's R-squared of 0.735180 shows that the variables of CAR, NPL, and LDR have a contribution of 0.735180 or $73.5180 \%$ to the measurement of banks' financial distress. Meanwhile, the remaining 
$26.482 \%$ of the variation in banks' financial distress is influenced by other variables that are not covered in this study.

\section{CONCLUSION}

Credit risk and liquidity risk have positive and significant effects in measuring the banks' financial distress. The higher the NPL and LDR are, the higher the possibility of the banks' financial distress will be. Meanwhile, liquidity risk has a direct relationship with banks' financial distress. The variable of capital adequacy has a negative and significant effect on the banks' financial distress. As a suggestion, to deal with situations like this, banks should apply prudent banking principles and make innovations in order to increase their income.

\section{ACKNOWLEDGMENT}

This research was supported and funded by the Institution of Research and Community-Engagement Services of Universitas Tarumanagara.

\section{REFERENCES}

[1] Agung Dharmawan Buchdadi, Xuan Tho Nguyen, Firman Risal Putra, and Sholatia Dalimunthe. (2020). The effect of credit risk and capital adequacy on financial distress in rural banks. International Journal Accounting, 6(6), pp.131-147. DOI:10.5267/j.ac.2020.7.023.

[2] Chiaramonte, L., \& Casu, B. (2017). Capital and liquidity ratios and financial distress. Evidence from the European banking industry. British Accounting Review 49 (2), pp.138-161. https://doi.org/10.1016/j.bar.2016.04.001

[3] Dahir, A. M., Mahat, F. B., \& Ali, N. A. Bin. (2018). Funding liquidity risk and bank risk-taking in BRICS countries: An application of system GMM approach. International Journal of Emerging Markets. 13 (1). pp. 231-248. https://doi.org/10.1108/IJoEM-032017-0086

[4] Dam, L., \& Koetter, M. (2012, August). Bank bailouts and moral hazard: Evidence from Germany. Review of Financial Studies. Vol.25, issue 8, pp. 23432380.https://doi.org/10.1093/rfs/hhs056

[5] Halim, C., Savitri, E., \& Diyanto, V. (2016). Analisis Pengaruh Rasio Keuangan dan Market Effect Untuk Memprediksi Kebangkrutan Bank Menggunakan Model Regresi Logistik (Studi Pada Bank yang
Terdaftar Di Bursa Efek IndonesiaPeriode 2008-2012). Jurnal Online Mahasiswa Fakultas Ekonomi Universitas Riau.Vol.3,No.1, pp.1294-1308.

[6] Hantono. (2017). Effect of Capital Adequacy Ratio (CAR), Loan to Deposit Ratio (LDR) and Non Performing Loan (NPL) to Return on Assets (ROA) Listed in Banking in Indonesia Stock Exchange. International Journal of Education and Research.Vol.5, No.1,pp.69-80.

[7] Imbierowicz, B., \& Rauch, C. (2014). The relationship between liquidity risk and credit risk in banks. Journal of Banking and Finance. vol. 40, issue C, pp.242-256. https://doi.org/10.1016/j.jbankfin.2013.11.030

[8] Irawati, N., Maksum, A., Sadalia, I., \& Muda, I. (2019). Financial performance of indonesian's banking industry: the role of good corporate governance, capital adequacy ratio, non performing loan and size. International Journal of Scientific and Technology Research.Vol.8,issue 4, pp.22-26.

[9] Jeanne, O., \& Svensson, L. O. (2017). Credible Commitment to Optimal Escape from a Liquidity Trap: The Role of the Balance Sheet of an Independent Central Bank. The American Economic Review. Vol.97, No.1,pp.474-490.

https://doi.org/10.1257/000282807780323361

[10] Junaidi, J. (2016). Pengukuran Tingkat Kesehatan dan Gejala Financial Distress Pada Bank Umum Syariah di Indonesia. Journal of Kinerja. Vol.20, No.1, pp. 42-52.https://doi.org/10.24002/kinerja.v20i1.696

[11] Kasmir. (2014). Bank dan Lembaga Kuangan Lainnya. Jakarta : PT. Raja Grafindo Persada.

[12] Mayes, D. G., \& Stremmel, H. (2012). The Effectiveness of Capital Adequacy Measures in Predicting Bank Distress. SSRN Electronic Journal. Vol 2014,1, pp.44-50.https://doi.org/10.2139/ssrn.2191861

[13] Nanda, R., \& Nicholas, T. (2014). Did bank distress stifle innovation during the Great Depression? Journal of Financial Economics. vol. 114, issue 2, pp.273-292.

https://doi.org/10.1016/j.jfineco.2014.07.006

[14] Nuranto, A. A., \& Ardiansari, A. (2017). Pengaruh Rasio Keuangan, Firm Size, dan Market Effect Terhadap Tingkat Kebangkrutan. Management Analysis Journal.Vol.6,No.2, pp.183-194.

[15] Ohlson, J. A. (1980). Financial Ratios and the Probabilistic Prediction of Bankruptcy. Journal of 
Accounting Research. Vol.18, No.1,pp.109-131.

https://doi.org/10.2307/2490395

[16] OJK. (2020). Peraturan Otoritas Jasa Keuangan

Nomor 6 /POJK.03/2016. www.ojk.go.id

[17] Umar, M., \& Sun, G. (2016). Determinants of different types of bank liquidity: evidence from BRICS countries. China Finance Review International. Vol. 6(4), pp. 380-403.

https://doi.org/10.1108/CFRI-07-2015-0113

[18] Wanke, P., Azad, M. A. K., \& Barros, C. P. (2016). Financial distress and the Malaysian dual baking system: A dynamic slacks approach. Journal of Banking and Finance. Vol. 6, No.4 (2020), pp. 861894.https://doi.org/10.1016/j.jbankfin.2016.01.006

[19] Wulandari, Y., Musdholifah, M., \& Kusairi, S. (2017). The impact of macroeconomic and internal factors on banking distress. International Journal of Economics and Financial Issues. Vol.7 (3), pp. 429-436 